Çanakkale Araștırmaları Türk Yıllığı

Yll: 13, Bahar 2015, Sayı: 18, ss. 637-656, 100. Yll

\title{
Savaşın Gölgesinde Yazılan Hikâyeler: Ömer Seyfettin'in Hikâyelerinde Savaşın Yansımaları
}

\begin{abstract}
Ahmet KOÇAK"
$\ddot{O} z$

Modern Türk hikâyesinin öncü isimlerinden Ömer Seyfettin (1884-1920), asker bir aileden gelmenin yanı sıra, kendisi de askerî eğitim almış, asker olarak görev yapmıştır. O, özellikle II. Meşrutiyet'in ilanından sonra bir asker olarak görev yaptığı Rumeli/Balkan coğrafyasında yaşanan siyasî gelişmelerin, çatışmaların yakın tanığı olmuştur. Onun hikâyelerinde askerlik hatıralarının, Balkan Savaşlarının öncesinden başlayarak, gerek cephede gerekse cephe gerisinde yaşanan siyasî ve sosyal olaylarl geniş tasviri yer alır. Özellikle savaşlar neticesinde ortaya çıkan menfaatperest, firsatçı tipler olumsuz tipler olarak işlenir. Bu makalede Ömer Seyfettin’in Balkan Savaşları öncesinden başlayarak Birinci Dünya Savaşı ve sonrasını ele alan, savașın gölgesinde yazılan hikâyelerinin değerlendirilmesi yapılacaktır.
\end{abstract}

Anahtar Kelimeler: Ömer Seyfettin, Rumeli/Balkanlar, hikâye, asker, savaş, çatışma

\section{Stories Written in the Shade of Wars: Reflections of Wars in the Stories of Ömer Seyfettin}

\begin{abstract}
Ömer Seyfettin (1884-1920), one of the leading names of modern Turkish story, was the son of a military official. He also got military education and served as an officer in the army.Particularly after the declaration of the Second Constitutional Monarchy, he was a close witness of the political developments and conflicts in Rumelia/the Balkans, where he served as an officer in the army. His stories include broad description of his military memoirs, and political and
\end{abstract}

Dr., Medeniyet Üniversitesi, Edebiyat Fakültesi, ahmet.kocak@medeniyet.edu.tr. 
social events experienced in and behind the battlefront, beginning before the Balkan wars. The self-seeking, opportunist type of people who especially show up as a result of the wars are depicted as negative types. In this article, the stories of Omer Seyfettin written in the shade of war during the period from before the Balkan wars till the end of the First World War will be taken into consideration.

Keywords: Ömer Seyfettin, Rumelia/Balkans, story, soldier, war, conflict

\section{Giriş}

Osmanlı devletinin altı yüz yıllık tarihinde en zor dönemini geçirdiği Balkan savaşları ve Birinci Dünya Savaşı yıllarında asker olarak bu savaşların cereyan ettiği coğrafyada bulunmuş isimlerden birisi de Ömer Seyfettin'dir. Onun bu dönemde kaleme aldığı fikrî yazılarının yanında hikâyelerinde de bu savaşların izlerini, yansımalarını okumak mümkündür. Onun hikâyelerinde bu konuların geniş yer almasının sebeplerinden birisi de, asker bir babanın oğlu olmasının yanı sıra kendisinin de askerî eğitim alması ve asker olarak görev yapmasıdır. Hatta annesi de bir asker kızıdır. ${ }^{1}$ Onun hikâyelerini bu açıdan değerlendirebilmek için kısaca hayat hikâyesine bakmak gerekir.

Ömer Seyfettin 11 Mart 1884 Gönen'de dünyaya gelir. ${ }^{2} 1896$ yılında Eyüp Askerî Rüştiyesi'ni bitirir. Daha sonra Edirne Askeri İdadîsi'ne devam eder. 1903 yılında Mekteb-i Harbiye-i Şâhâne'den mezun olur. Meslek hayatına, o sıralarda merkezi Selanik'te bulunan Üçüncü Ordu'nun Redif tümenine bağlı Kuşadası Redif taburunda başlar. ${ }^{3}$ Ancak Nazım Hikmet Polat'ın aktardığına göre, Ömer Seyfettin İzmir'e gelmeden önce "Rumeli'de Selanik'te ve Manastır'a bağlı Pirlepe'de görev yapmıștır”." Bir yıl sonra asıl görev yeri olan Kuşadası'na dönen asker Ömer Seyfettin, 1906 yılında İzmir'de yeni açılan Jandarma okuluna nakledilir. 1909 yılı başlarında Selanik Üçüncü Ordu merkezine tayin edilen Ömer Seyfeddin, iki yıl süreyle Rumeli'de Manastır, Pirlepe, Köprülü, Cuma-yı Bâlâ, Velmefçe, Osenova, Pirbeliçe, Serez, İștip, Babina,

1 Nâzım Hikmet Polat,“Ömer Seyfettin Hakkında”,Ömer Seyfettin, Bütün Hikâyeleri (hzl. N. Hikmet Polat, Yapı Kredi Yayınları, İstanbul2011) içinde, s. 15; Tahir Alangu, Ömer Seyfettin:Ülkücü Bir Yazarın Romanı,May Yayınları, İstanbul 1968, s. 26.

2 Sadık Tural, “Ömer Seyfeddin'in Hayatı ve Eserleri”, Doğumunun 100. Yllında Ömer Seyfeddin, Marmara Üniversitesi Yayınları, İstanbul 1984, s. 9; Nazım Hikmet Polat, "Ömer Seyfettin," TDV İslam Ansiklopedisi (DIA), İstanbul 2007, c. 34, s. 80-82; Ömer Seyfettin, Makaleler-1 (hzl. Hülya Argunşah), Dergâh Yayınları, İstanbul 2001, s. 5-16.

3 Alangu, a.g.e., s. 85-86

4 Ömer Faruk Huyugüzel, “Ömer Seyfettin'in İzmir Yılları ve Bu Devrede Verdiği Eserler,'Izmir'de Edebiyat ve Fikir Hareketleri Üzerine Araștırmalar, İzmir Büyükșehir Belediyesi Yayını, İzmir 2004, s. 210. 
Demirhisar kasabalarını dolaşır, Serez Mutasarrıflı̆̆ı'na bağlı Menlik sancağının Razlık kasabasına yakın Yakorit Köyü'nde bölük komutanlığı görevinde bulunur. ${ }^{5} 1909$ yılında Hareket Ordusu'yla kısa süreliğine İstanbul'a gelen Ömer Seyfettin, 1911 y1lında Ziya Gökalp'in de talebi ile ordudan ayrılarak Selanik'e yerleșir. ${ }^{6} 1912$ yılında Balkan Harbi'nin patlak vermesiyle Ömer Seyfeddin, Garp Ordusu emrinde Sirp ve Yunan cephelerinde savaşmak üzere orduya çağrılır. Yanya kuşatması sırasında Yunanlılara esir düşer. Atina yakınlarında Nafliyon kasabasında on ay kadar esir kalan Ömer Seyfettin, 15 Kasım 1913'de kurtulur ve İstanbul'a gelir. 1914 yılında tekrar askerlikten ayrılarak Kabataş Sultanisi'nde ve İstanbul Erkek Muallim Mektebi'nde edebiyat öğretmenliği yapar. 6 Mart 1920'de Haydarpaşa Tıp Fakültesi'nde vefat eder. ${ }^{7}$

Edebiyat dünyasına on altı yaşındayken (1900) şiirle adım atan yazar ${ }^{8}$, otuz altı yıllık kısa sayılabilecek hayatında makale, şiir, fıkra, mektup, piyes gibi farklı edebî türlere ait pek çok eserin yanı sıra 160'a yakın hikâye yazarak alanın en önemli isimlerinin başında gelir. ${ }^{9}$ Modern Türk hikâyesinin öncü isimlerinden Ömer Seyfettin, bir asker ve yazar olmanın ötesinde, dönemin aydın insanlarından birisidir. Dolayısıyla hikâyelerini kaleme alırken, askerlik anılarının yanı sıra bir aydın olarak Osmanlı Devleti'nin karşı karşıya kaldığı büyük sorunlara çözüm önerileri getirmeye çalışmış, bunu çeşitli meseleler üzerine yazdığı makale, köşe yazısı ve hikâyelerle dile getirmiştir. Meşrutiyet'in ilanı, akabinde bir asker olarak yer aldığı Balkan savaşları ve terkedilmek zorunda kalınan Balkanlar'daki önemli topraklar, yazarın ruh dünyasında derin izler bırakmıştır. ${ }^{10}$ Bütün bu yaşananlar,aynı zamanda bir tanık olarak Ömer Seyfettin'in hikâyelerine çarpıcı bir biçimde yansımıştır. Hikâyelerinde kendisini gösteren "yirminci yüzyılda yaşama şuuru ve gerçekçilik, mazi ve kahramanlık hasreti, duru bir Türkçe, buruk bir mizah"11 gibi temel özellikler, onun hikâyelerinin genel özellikleri olarak da okunabilir. Onun II. Meşrutiyet'in ilanından sonra başlayıp vefatına kadar yazdığı hikâyeleri, savaşın yansımaları açısından üç başlık altında değerlendirilebilir. Bunlardan ilki, II. Meşrutiyet'in ilanından Balkan savaşlarının bitimine kadar, yani yazarın bir asker olarak Rumeli/Balkanlarda yakın tanığı olduğu dönemi işleyen hikâyelerdir. ${ }^{12}$ İkincisi, bir yazar ve aydın olarak Birinci Dünya Savaşı'nı konu

5 Ömer Seyfettin, Bütün Hikâyeleri, s. 80.

6 Tural, a.g.e., s. 10-11.

7 Tural, a.g.e., s. 11-12; Polat, “Ömer Seyfettin”, s. 80; a.mlf., “Ömer Seyfettin Hakkında”, s. 15-34.

8 Tural, a.g.e., s. 13; Nazım Hikmet Polat, Şair Ömer Seyfettin Bütün Şiirleriyle, Türk Dil Kurumu Yayınları, Ankara 2014, s. 35.

9 Polat, "Ömer Seyfettin Hakkında", s. 19.

10 Murat Koç, “Ömer Seyfettin’in Eserlerinde II. Meşrutiyet ve İttihat ve Terakki”, Bilig, 47,Güz2008,s. 145.

11 İnci Enginün, “Ömer Seyfettin’in Hikâyeciliği”, Doğumunun Yüzüncü Yılında Ömer Seyfettin, Atatürk Kültür, Dil ve Tarih Yüksek Kurumu Atatürk Kültür Merkezi Yayınları, Ankara 1992, s. 38.

12 Alaattin Karaca, “Ömer Seyfettin'in Hikâyelerinde Balkanlar”, Bir Dünya Yazarı Ömer Seyfettin Sempozyumu Bildirileri, İstanbul Büyükşehir Belediyesi Yayınları, İstanbul 2011, s. 77. 
edindiği hikâyeleri; üçüncüsü ise, savaşın gölgesinde ve sonrasında gelişen sosyal hayattaki değişik yansımaları işleyen hikâyeleridir.

\section{Savaşın Gölgesinin Düştüğü Hikâyeler}

Yirminci yüzyılın başlarında Osmanlı coğrafyası içerisinde en karışık ve problemli bölge Rumeli/Balkanlar'dır. Balkan savaşlarının hemen öncesinde Türk, Bulgar, Sırp, Makedon, Arnavut, Boşnak gibi farklı milliyetlerden oluşan bu coğrafya, özellikle Avrupa'nın ve Rusya'nın kışkırtmalarıyla en hareketli bölgelerden birisi haline gelmişti. ${ }^{13}$ Ömer Seyfettin, Balkanlar'daki Osmanlı karşıtı milliyetçilik havasının yakından şahidi olur. ${ }^{14}$ Makedon ve Bulgar komitacıları, sadece bölgede yaşayan Türklere değil, kendi halklarına da zulüm ve şiddet uygulamaktadırlar. ${ }^{15}$

Ömer Seyfettin'in bölgedeki komitacıların vahşi cinayetlerini konu alan hikâyelerinden birisi, 1911 yılında kaleme aldığı "Bomba"dır. Hikâyede, sosyalist düşüncelere sahip Boris, komitacılardan ayrıldıktan sonra bütün mallarını satıp hamile eşini de alarak, Amerika'ya göç etmek ister. ${ }^{16}$ Ancak bu planın komitacılar tarafından öğrenilmesi, "hain" olarak ilan edilmesi için yeterli bir sebeptir. Daha önce komitac1lardan tehdit mektupları alan Boris, Amerika'ya kaçış planını gizli şekilde yürüterek son gece eşine bunu açıklar. Ancak o gece komitacılar tarafından babasının evi basılır. Önceleri kendisi de bir komitacı olduğu için gelen komitacıları ikna edebileceğini düşünerek onlarla konuşmaya gider. Komitacılar kendilerine ihanet ettiğini düşündükleri Boris’i katletmek ve göç için satılan bütün malların parasına el koymak niyetindedirler. Nitekim bu doğrultuda önce onu vahşice öldürürler, kellesini "Bomba" şeklinde bir bohçaya sararak eşinin bulunduğu eve getirirler. Burada parayı almak için Boris'in eşi Magda'yı ve yaşlı babası İstayon'u ölümle korkutup taciz ederler. Sabaha kadar yaşlı adamın gözleri önünde Boris'in hamile eşi Magda ile eğlenirler. Sabahın ağaran ışıklarıyla birlikte saklanan paraları da alarak evden ayrılan komitacılar, Magda'ya çeyiz sandığında saklaması için “Bomba” bırakırlar. Aslında bırakılan şey, Boris'in kesilen başıdır. ${ }^{17}$ Yazar, II. Meşrutiyet sonrası devlet otoritesinin zayıfladığı

13 Balkanlarda siyasi ve etnik çatışmaların geniş bir değerlendirmesi için bkz. Mehmet Güneş, "XX. Yüzyılın Başlarında Balkanlardaki Siyasî ve Etnik Çatışmaların Ömer Seyfettin’in Hikâyelerine Yansıması", TÜBAR, Bahar 2011, s. 163-187.

14 Erol Köroğlu, Türk Edebiyatı ve Birinci Dünya Savaşı (1914-1918): Propagandadan Millî Kimlik İnşasina, İletişim Yayınları, İstanbul 2004, s. 353.

15 Önertoy, Ömer Seyfettin'de milliyetçilik düșüncesinin uyanmasına ve gelișmesine 1909-1911 yılları arasında Makedonya sınır boylarında geçirdiği günlerin etkili olduğunu ifade eder. Bkz. Olcay Önertoy, "Ömer Seyfettin'in Milliyetçilik Düșüncesi”, Doğumun 100. Yilında Ömer Seyfettin, Türk Tarih Kurumu Basımevi, Ankara 1992, s. 74-75.

16 Ömer Seyfettin'in savaş yıllarında yazdığı hikâyelerden sadece "Bomba"da değil, "Ashab-1 Kehfimiz", "Nakarat" gibi başka hikâyelerinde de Amerika huzur ve mutluluğun ülkesi olarak tasvir edilir. Bkz. Ömer Seyfettin, Bütün Hikâyeleri, s. 202-218, 302; 798-814, 803.

Ömer Seyfettin, Bütün Hikâyeleri, s. 215. 
bu coğrafyada bölge insanının, hatta kendi soydaş/dindaşlarının komitacılar tarafından nasıl zulüm ve işkenceye maruz bırakıldığının bir örneğini sunar. ${ }^{18}$

Savaşlar asırlarca bir arada yaşayan insanların etnik bilincinin ortaya çıkmasına, ailelerin dağılmasına ve yıkılmasına sebep olmaktadır. Ömer Seyfettin'in, Balkan savaşlarının hemen arifesinde cereyan eden Trablusgarp Muharebesi'ni konu alan ve aynı zamanda askerlik hatıralarını da içeren ${ }^{19}$ hikâyelerinden bir diğeri de "Primo Türk Çocuğu"dur.

Genç mühendis Kenan Bey, ecnebî ve Levanten mahfillerinde yetişmiş, mensubu olduğu Türklüğe yani "medeniyetsizliğe" karşı taassup derecesinde nefret duyan, Avrupa âdâb-1 muâşeretine vukufuyla bilinen, Paris'te eğitimini tamamlamış, dönünce de İzmir'de dolgun bir maaşla işe başlamış birisidir. Kenan Bey, harbi hiç sevmez, "Harp hayattır" diyen feylesoftan da nefret eder. Levanten ve mason çevrelerde yetişen, Avrupa'da eğitim gören Kenan Bey için "fazilet ve insaniyet” fikrinin dışında bir değer de yoktur. Ancak savaş her millet için, idraki olan her insan için bir uyanış, aslına dönüştür. Nitekim Avrupa'da eğitim görmüş, Avrupalı olmak için her şeyini feda etmiş Kenan Bey, sadık kardeș olarak gördüğü dostları arasında mühim bir nüfuz ve itibara da sahip olmuştur. Bir mason olduğu için yakında terfi ederek "grandmetr" bile olacaktır. ${ }^{20}$

Eşi İtalyan Grazia ile İzmir'de bir baloda tanışan Kenan Bey, aynı gece kendisi gibi mühendis olan kızın babasıyla da tanışır. Baba Vitalis'in hükümet nezdinde halledilecek birçok işleri olduğu için, Avrupa'da eğitim görmüş, Avrupalı yaşam tarzını seçmiş Kenan gibi birisine ihtiyacı olduğundan onu yanında işe alır. Kenan kızıyla evlenmek istediği zaman ise, buna şiddetle karşı çıkar. Ancak kızının da Kenan'a aşık olması kararını yumuşatır. Baba kız, bir Avrupalı gibi yaşayan Kenan’n Türk olamayacağına, Bizans döneminden kalma bir Rum çocuğu olabileceğine kendilerini inandırınca rahatlarlar. Milli bilinci yüksek olan Vitalis, kızını verirken de bazı şartlar ileri sürmüştür. Hatta doğacak çocuklarını bile İtalyan terbiyesine göre yetiştirmelerini ister. Doğan çocuklarına da İtalyan ismi olarak Primo ve Sekundo adını verirler. Mösyö Vitalis II. Meşrutiyet'in ilanından sonra işlerin iyi gitmeyeceğini düşünerek beș parasız geldiği buradan, İtalya'ya büyük paralarla döner. ${ }^{21}$

Kenan'ın milli bilincinin uyanmasına vesile olan da savaştır. Onun zihni, iş için geldiği Selanik'te "işittiklerinin, gördüklerinin, gazetelerde, ilavelerde okuduklarının sahih olduklarına akıl erdiremeyecek" kadar karışık durumdadır. Savaşın sıkıntısını

18 Güneş, a.g.m.s. 168-170.

19 Ömer Seyfettin'in askerlikle ilgili görüşleri hakkında bkz. İbrahim Torun, “Ömer Seyfettin’in askerlikle ilgili görüşleri ve Öykülerinde Asker Tipler”, Türk Dili, 634, Ekim 2004, s. 477-488.

20 Ömer Seyfettin, Bütün Hikâyeleri, s. 366-369.

21 Ömer Seyfettin, Bütün Hikâyeleri, s. 377. 
ruhunda hissetmeye başlayan Kenan'ın aklına, insaniyete hizmet eden Avrupalıların Afrika'da yaptıkları sömürüler gelir. Onların Afrika'yı kendi aralarında paylaşmalarından sonra sıranın Osmanlı'ya geldiğini fark eder. Avrupalıların Asya'nın taksimine engel gördükleri Türkiye’yi de zayıf bırakmak, mahvetmek düşüncesine sahip olduklarını düşünür. İtalya da Osmanlı'ya ait Trablusgarp'a saldırmıştır. Hâlbuki İtalya'yı yöneten insanlar, "Yalnız insaniyet, başka bir şey yok." sloganını kullanmaktadırlar. ${ }^{22}$

Avrupalıların Afrika'da, İtalyanların Trablus'ta yaptıklarının gerçek yüzünü ve "insaniyet" diye ortaya çıkanların kendileri gibi olmayanları sömürmek, ezmek d1şında bir şey düşünmediklerini anlayan Kenan Bey, kendi ruh dünyasında firtınalar yaşar. O, kendi iç dünyasında yaşadığı çekişmelerden sonra oğlunun geleceğini, Avrupa'dan döndüğü yılları, eşiyle tanışmalarını düşünür. Meydanda biriken kadın ve erkekler kendi aralarında "yeni başlayan harbi, düşman filosunun muzafferiyetini" konuşurlar.

Savaşın gölgesi düşünce Kenan Bey'in İtalyan eşi Grazia, ilk firsatta çocuğunu da alarak İtalya'ya kaçmak ister. O, Türklerin bilmediği harple ilgili bütün bilgileri ecnebilerden öğrenmiş, İngiltere, Almanya, Fransa hâsılı bütün Avrupalıların bir yıl içinde Şark meselesini yani Osmanlı'yı halledeceklerini öğrenmiştir. Dolayısıyla ortalık karışmadan buradan uzaklaşmak gerektiğini söyler. ${ }^{23}$ Kenan'la eşi Grazia kendi aralarında taşınma/mayı konuşurken oğulları Primo da, gelişen olayları çevreden öğrenmiş ve babasıyla kalmaya karar vermiştir. Yazar, mesaj vermeyi ihmal etmez: "Büyük tecavüzler, büyük felaketler daima büyük inkılaplara başlangıç olmaz mıydı?" ${ }^{24}$

Günlükler şeklinde kaleme alınan "Ashâb-1 Kehfimiz"25 hikâyesinde ise, Kur'an'da adı geçen bir kıssaya atıf yapılarak, savaşın gölgesi toplumun üzerindeyken, farklı gündemlerle uğraşan insanların hâli Ashâb-1 Kehf'in durumuna benzetilir. ${ }^{26}$

Meşrutiyet'in ilanından sonra İstanbul'a ayrı bir hava gelmiş, halk hürriyetin neşesiyle sevinç içindedir. Dinler ve milletler kaynaşmıştır. Ancak bu günler çok sürmez. Herkes farklı cemiyetler kurarak dönemin siyasî akımları etrafında fikir üretmeye başlar. ${ }^{27}$ Bunlardan birisi de Avrupa'da hukuk eğitimi görmüş, yazarın bir vesile ile

22 Ömer Seyfettin, Bütün Hikâyeleri, s. 371-372.

23 Ömer Seyfettin, Bütün Hikâyeleri, s. 384.

24 Ömer Seyfettin, Bütün Hikâyeleri, s. 391.

25 Ömer Seyfettin'in daha önce "Küçük Hikâye" başlığı altında yazdığı hikâyenin devamı sayılan ve "Ashâb-ı Kehfimiz, İctimaî Roman" başlığı altında yazdığı bu hikâyesi, her ne kadar 1918'de yayımlanmış olsa da daha çok 1908-1913 yılları arasında tutulan günlüklerden oluşur. Daha geniş bilgi için bkz. Ömer Seyfettin, Bütün Hikâyeleri, s. 282, 288-340.

26 Kur'an'da, yaşadıkları dönemin kralının zulmünden kaçarak bir mağaraya sığınan ve orada üç asırdan fazla uyuduktan sonra uyandırılan altı insan ile onlara eşlik eden köpeklerinin hikâyesi anlatılır (Kehf 8/110). Askerlik hatıraları ve savaşın izlerini taşıyan bu hikâyesinde Kehfsûresine atıf yapan Ömer Seyfettin, Birinci Dünya Savaşı’nın hemen arifesinde yayımlanan "Mehdi" hikâyesinin başına da Hûd sûresinden bir ayet alır. Bkz. Ömer Seyfettin, Bütün Hikâyeleri, s. 341.

27 Dönemin fikir akımları karşısında Ömer Seyfettin'in yeri konusunda bkz. Sabahattin Çağın, "Fikir Akımları Karşısında Ömer Seyfettin", Ömer Faruk Huyugüzel'e Armağan (ed. Halef Has), Ege Üniversitesi Basımevi, İzmir 2010, s. 223-234. 
tanıştığı Niyazi Bey'dir. Niyazi Bey ve arkadaşları “Osmanlılı” düşüncesi etrafında Türklerden başka, Levanten, Rum, Ermeni, Arap, Bulgar, Yahudi milletlerinden insanların yer aldığı "Osmanlı Kaynaşma Kulübü”nü kurarlar. Ancak kulübe Türklerin dışında devam eden olmadığı gibi, her hafta konuşulan ve dile getirilen meseleler gerçekleşmesi mümkün olmayan hayalperest fikirlerdir. ${ }^{28}$ Yazar, Balkan Savaşı'nın başladığı günleri ve toplumda oluşan havayı şöyle aktarır: "Harp başladı... Bulgarlar, Sırplar, Karadağlılar, Yunanlılar hatta bir parça da Arnavutlar, Türklere ilan-1 harp ettiler." ${ }^{29}$ Savaş kısa sürede tesirini gösterir. İşler bozulur, piyasa durgunlaşır, her taraf Rumeli/Balkanlar'dan gelen muhacirlerle dolar. Sefalet hat safhadadır. Halk arasında da İstanbul'un Avrupa yakasından Üsküdar, Kadıköy gibi Anadolu yakasına göçler başlamıștır. Tüm bunlar olurken İstanbul'da yaşayan gayrimüslim Osmanlı vatandaşları gelişmelerden memnundurlar. Onlar Kostantin'in müttefikleriyle birleşerek, "on beş yirmi güne kadar" İstanbul’a geleceği beklentisi içindedirler. Hem azınlıklar hem de Türkler "İstanbul'un son günlerini yaşadığına" inanmaktadır. ${ }^{30}$

Halkın teslim olma psikolojisine sokulduğu bu dönemde, özellikle Avrupa'da eğitim görmüş, milli bilinç erozyonuna uğramış pek çok Osmanlı Türk aydınının peşine takıldığı fikirlerin de bir faydası yoktur. Dolayısıyla Balkan Savaşı "Osmanlılık" düşüncesinin de iflas ettiğini göstermiștir. ${ }^{31}$

Yazar, II. Meşrutiyet sonrası kurulan “Osmanlı Kaynaşma Kulübü”nde konuşulan fikirlerin ve burada dile getirilen düşüncelerin ne kadar gerçeklerden uzak olduğunu on iki sene sonra "Ey Ashâb-ı Kehf! Sizin Türkiye'de dilinizi anlayan yoktur. Yine mağaranıza kapanınız, ezelî uykunuza dalınız." ifadeleriyle dile getirir. ${ }^{32}$ Balkan savaşları sonrasında müttefik orduları İstanbul'a girememiştir, ancak Rumeli/Balkanlar'dan muhaceret etmek zorunda kalan Türklerin geride bıraktı̆̆ı bölgelerde Bulgarlar İslam'ın simgesi olan cami ve minare bırakmamışlardır.

Ömer Seyfettin'in askerlik hatıralarından izler taşıyan ve savaşın gölgesinde yazılan başka bir hikâyesi de "Mehdi"dir. Yazar, bir asker olarak bulunduğu Serez istasyonundan Selanik'e gidecek olan bir trene binişinden başlayarak, yolculuk esnasında ve sonrasında savaşın izlerini aktarır. Serez istasyonundan ikinci mevki kompartımana binenlerin hepsi Müslüman ve Türk'tür. Türk askerinin bölgeden çekilmesiyle her șey değişmiş, farklı bir kimliğe bürünmüştür. Seyahat boyunca Balkan Savaşları sonrasında bölgenin sosyal ortamı, Türkler aleyhine değișen manzarasını şu şekilde tasvir edilir:

28 Ömer Seyfettin, Bütün Hikâyeleri, s. 313-318.

29 Ömer Seyfettin, Bütün Hikâyeleri, s. 324.

30 Ömer Seyfettin, Bütün Hikâyeleri, s. 326.

31 Koç, a.g.m., s.124.

32 Ömer Seyfettin, Bütün Hikâyeleri, s.337. 
"Geçen felaket ve bozgun yılının canlanmış da kalmış uğursuz ve karanlık damlalarına benzeyen birçok karga sürüleri sahipleri öldürülen boş ve sürülmemiş tarlalarda dolaşıyordu. Hava pek soğuktu. Kapalı camların ince buğularından minareleri yıkılmış, mescitlerinin üzerine haçlar asılmış tenha köyleri görüyor gibi oluyorduk. Bu köyler uzaklarda, ta ufkun nihayetindeki mor sislerin içinde idi. Şimdi ezanın sustuğu bu öksüz yurtlara çanlarını ulutmak için Selanik'e vapur vapur gelen Kafkasya Rumları yerleşiyorlardı. Susuyorduk. Ve sanki bize milyonlarca kan ve din kardeşlerimizin ölümünü hatırlatan dışarısını, bu düşmanın öz vatanımızdan zorla kopardığı altın sahraları görmemek için önümüze bakıyorduk."33

Rumeli/Balkanlarda yaşayan Müslüman Türklerin manzarası ne kadar yürek burkucu ise, Rumların ve diğer milletlerin durumu bunun tam tersidir. Nitekim daha sonraki istasyonlardan birinden trene binen bir Rum vatandaşı, içtiği sigaranın dumanını Türklerin üzerine üflerken avazı çıktığı kadar da "Bizans İmparatoru ve Yunanistan Kralı" adına bestelenmiş şarkıları söyler. ${ }^{34}$

Ömer Seyfettin'in Balkan Savaşlarının öncesinde kaleme aldığı "Primo Türk Çocuğu" (Nasıl Doğdu?) hikâyesinin devamını savaş sonrasında da "Primo Türk Çocuğu “ (Nasıl Öldü?) ile devam ettirir. Trablusgarp savaşının başlamasıyla Kenan Bey’in eşi çocuğunu da bırakarak İtalya'ya gider. Savaş ortamı vesilesiyle milli bilincini ve kimliğini yeniden kazanan Kenan Bey, oğlunun ismini de İtalyanca Primo'dan Türkçe Oğuz'a değiştirir. Çocuğun eğitimi de Fransız mektebinden Türk okuluna alınır. ${ }^{35}$ Yerli değerler ve milli bilinçle yetişen çocuk, nihayet bir cuma günü toplanan kalabalıktan "seferberlik" ilan edildiğini duyar. Bu ilanın Bulgarlara karşı olduğunu öğrenir. Ancak eve geldiği zaman, evdeki hizmetçi hanımdan muharebe demenin bir felaket olduğunu, "muhacirlik olacak, çoluk çocuk meydanda kalacak" demek olduğunu öğrenir. ${ }^{36}$ Muharebe ilk önce Karadağ’da başlamış, kısa süre sonra da Bulgarlar, Yunanlılar ve Sırplar da savaş ilan etmişlerdir. Selanik şehri, Koçana'dan, İştip’ten, Köprülü'den gelen muhacirlerle dolup taşmıştır. Savaşın getirdiği en acı manzara açlık ve sefalettir. Zavallıların hepsi açtır. "Allah aşkınıza biraz ekmek" diye yalvarırlar. ${ }^{37}$

Sabahleyin her taraf "Zito, zito Yorgos" naraları mavi beyaz bayraklarla donanır." Kenan Bey, ertesi gün İstanbul'a doğru yola çıkmak üzere hazırlık yapsa da, Yunan askerleri tarafindan tutuklanır. Primo'ya babası birkaç gün sonra serbest kalacağını ve İstanbul'a döneceklerini söyler, ancak Primo'nun muhacirlerden duydukları şeyler hep ürkütücüdür.

33 Ömer Seyfettin, Bütün Hikâyeleri, s. 341

34 Ömer Seyfettin, Bütün Hikâyeleri, s. 347.

35 Ömer Seyfettin, Bütün Hikâyeleri, s. 393-394.

36 Ömer Seyfettin, Bütün Hikâyeleri, s. 399.

37 Ömer Seyfettin, Bütün Hikâyeleri, s. 401. 
Düşmanlar hep Türk köylerini sarmakta, kadın ve kızlara tecavüz edip öldürmektedirler. Erkeklerin hepsini kurşuna dizmektedirler. Küçük çocukları da Hıristiyan yapmak üzere Yunanistan'a gönderirler. Amaçları da Rumeli'de Türk namına bir şey bırakmamaktır. Garplıların "temizleme" adını verdikleri uygulamaların benzer örnekleri daha önce İspanyollar tarafından Endülüs'te Araplara, İtalyanların Trablus'ta tatbik ettikleri bir usuldür. ${ }^{38}$ Babası tutuklanan Primo, İstanbul'a taşınmaya karar verince, yetişmiş olduğu bilinçle aşçı hanımının oğlundan aldığı emanet silahı, "Beş yüz senedir Türklerin elinde duran Selanik'i aldık da bize silah atılmadı." demesinler diye yanında taşır..$^{39}$

Ömer Seyfettin'in Balkanlarda yaşayan Türklere karşı uygulanan zulmü en çarpıc1 şekilde işlediği "Beyaz Lâle"yi İnci Enginün, "Bulgar zulmünü en yoğun şekilde" işlediği hikâye olarak görür. Yazarın "vatanî hikâye" üst başlığı ile "Bedbaht Rumeli Müslümanlarına" ithaf ettiği bu hikâyede, "Primo Türk Çocuğu"nda olduğu gibi Yunanistan'ın Orta Makedonya bölgesinde bulunun Serez'de geçmektedir. Birinci Balkan Savaşı'ndan sonra bölgeden Türk askerinin çekilmesinden sonra ${ }^{41}$ şehri işgal eden Bulgar komitacıları, bölgeyi Türklerden arındırmak amacıyla, sistematik bir işkence ve zulüm uygulamaya başlarlar. ${ }^{42}$ Balkanlarda Türk askerinin beklenilmeyen bozgunu, Hıristiyanları sevince boğmuştur. ${ }^{43}$

Yazar asker olarak bulunduğu bölgedeki zulüm ve işkenceleri aktarırken, bilincin uyanmasına da vesile olur. ${ }^{44}$ "Primo Türk Çocuğu”nda Avrupa'da eğitim görmüş, onlara özenmek için her şeyini feda etmeye hazır bir Türk gencine karşılık, bu kez İstanbul'da eğitim görmüş, ancak Büyük Bulgaristan hedefiyle yetişmiş bir Bulgar askerini hikâyenin merkezine koyar. Galatasaray Sultanisi'nde okumuş olan Radko'nun en büyük ideali "Büyük Bulgaristan İmparatorluğu”nu kurmaktır. ${ }^{45}$

Makedonya ve Bulgar bölgesinde zulmü ile tanınan Radko'nun öncelikli hedefi, Serez bölgesinde yaşayan Müslüman Türk nüfusunu temizlemektir. Bunun için plan-

38 Ömer Seyfettin, Bütün Hikâyeleri, s. 411.

39 Ömer Seyfettin, Bütün Hikâyeleri, s. 414.

40 İnci Enginün, “Ömer Seyfettin'in Hikâyelerinde Yabanclar”, Doğumunun Yüzüncü Yılında Ömer Seyfettin, Marmara Üniversitesi Yayınları, İstanbul 1984, s. 53.

41 Osmanlı'nın Balkanları bırakmasının edebiyata yansıması konusunda bkz. Halûk Harun Duman, Balkanlara Veda, Duyap Yayınları, İstanbul 2005.

42 Yavuz Demir, “Ömer Seyfettin'in Hikâyelerinde Bulgar Zulmü”, Türk Edebiyatı, 170, Aralık 1987, s. 59-60.

43 Ömer Seyfettin, Bütün Hikâyeleri, s. 426-427.

44 Enginün'e göre, farklı milletlerden insanların bir arada yaşadığı Osmanlı Devleti'nin yıkılıș sürecine girmesinden sonra kurtuluşun Türklük şuurunun uyanması ve milli benliğe sahip çıkılmasıyla gerçekleşeceğine inanan Ömer Seyfettin, "Primo Türk Çocuğu" ve "Nakarat" gibi hikâyelerde bu uyanışı anlatmaktadır. Bkz. İnci Enginün, “Ömer Seyfettin'in Hikâyeleri”, Yeni Türk Edebiyatı Araștırmalarl-1, Dergâh Yayınları İstanbul 2012, s. 169.

Ömer Seyfettin, Bütün Hikâyeleri, s. 428. 
lar hazırlar. Buna göre, bölgede kalan Türklerin evlerinde ve bankalarındaki paralara zorla el konulacak, bütün malları Bulgar mekteplerine devredilecektir. Kalanların hepsi vaftiz edilerek Hıristiyan yapılacak ve katledilecektir. ${ }^{46}$ Hastalıklı bir ruh haline sahip olan Radko, aşırı Bulgar milliyetçisidir. Esas hedefi olan Büyük Bulgaristan İmparatorluğunu kurmak için de, kendi milletinden olmayan herkesin ortadan kaldırılması gerektiğine inanmaktadır. Bu ruhun yansıması olarak okunabilecek Radko'nun düşünce dünyası ile, daha önce bölgede asırlarca hakimiyet kurmuş, yaşlılara, kadın ve çocuklara savaş ortamında bile dokunmamayı prensip edinmiş Türkler arasında insanlık bakımından ne kadar fark olduğu da dile getirilir:

"Düşünmek ister. Biz çocukları kesmeyeceğiz. Yarının büyük adamlarını keseceğiz. Genç bir kadın karnından on beş tane düşman çıkarabilir. Bir genç kadını yahut bir kızı öldürmek on beş düşman birden öldürmek demektir. Eğer Türkler buraları aldıkları zaman yaşlılarının sözlerini dinlemeyip hepimizi kesselerdi, bugün bir Bulgaristan olacak mıydı? Biz böyle onları önümüze takıp kovalayabilecek miydik? Yanıldılar. Fırsat ellerindeyken kadınlarımızı, çocuklarımızı kesmediler. Kesilmeyen Bulgarlar çiftleşe çiftleşe çoğaldılar, güçlendiler. Merhametli yani zayıf hâkimlerinin altından kalktılar. İşte şimdi de tepesine bindiler."47

Savaş ortamlarında en çok mağdur olanlar çocuklar ve kadınlardır. Bulgar Radko'nun da hedefinde kadınlar vardır. Cuma'dan Osenova'dan seçip getirilen on dört on beş yaşındaki kızları askerlerine sunar. Onlarla sabahlara kadar eğlendikten sonra hepsi katledilir. Radko ise, kendisine Serez'in en güzel kızı, Hacı Hasan Efendi'nin on dokuz yaşındaki Lâle (Lâli)'yi seçer. Lâli'nin babasını katleden Radko, onun evine giderek kıza tecavüz etmeye kalkışır, ancak o evin penceresinden atlayarak intihar eder. Radko, pis emelini kızın ölen cesedi üzerinde gerçekleștirir. ${ }^{48}$ Hikâyede diğer kadınlar, Lâle gibi intihar etme fırsatı bulamamış, işkence ile öldürülmüşledir. ${ }^{49}$

“Gençliğini Makedonya'da geçirmiş eski bir zabitin hatırat defterinden...” notunu düştüğü "Nakarat" hikâyesi de benzer şekilde Perlibeçe, Babina, Velmefçe gibi yazarın asker olarak bulunduğu bölgelerde geçer. ${ }^{50}$ Bölgede en büyük sıkıntı komitacılardır. Komitacılar tarafından bölge halkı sürekli baskı ve zulüm altındadır. Anlatıcı

46 Ömer Seyfettin, Bütün Hikâyeleri, s. 428.

47 Ömer Seyfettin, Bütün Hikâyeleri, s. 431-432.

48 Ömer Seyfettin, Bütün Hikâyeleri, s. 455.

49 Sema Uğurcan, “Ömer Seyfettin'in Hikâyelerinde Kadın Tipleri”, Edebiyatımız-II: Yazarlar, Meseleler, Dergâh Yayınları, İstanbul 2012, s. 276.

50 Enginün, Ömer Seyfettin'in bir asker olarak devletin tehlikede olduğu gerçeğini Rumeli'de bilhassa Bulgarlar arasında iken gördüğünü söyler ve onun kuvvetli milli şuura sahip olmasını da buraya dayandırır. Bkz. Enginün, "Ömer Seyfettin'in Hikâyeleri”, s. 173. 
on gündür sonbaharla sararmış harap ormanlarda, komitacıların erzak depolarını aradıklarından bahseder. ${ }^{51}$

Ömer Seyfettin'in askerlik ve savaş etrafında işlediği hikâyelerindeki temel özelliği, milli bilinç ve iki zıt karakterin bir arada verilmesidir. Türk olmayan unsurlar milli bilinç konusunda kadını ve erkeğiyle aşırı hassasken, Türklerde bu bilinçlenme ya bir olay sayesinde, ya da savaş sebebiyle gerçekleşir. Hikâyede Türk askeri, birliğin karşısındaki evde gördüğü ve adını bilmediği Bulgar kızına aşık olur. Ancak kız askeri her gördüğünde "Naş, nal, Çarigradnaş... rasvatri' sözlerini tekrarlar. Safiyane duygularla "seni çok seviyorum, senin için ölüyorum.!"52 demek olduğunu zanneden Türk askeri, "Bizim olacak, bizim olacak, İstanbul bizim olacak." Manasına geldiğini son gün öğrenir. ${ }^{53}$ Bulgar kızı sayesinde milli bilince varan asker, daha sonra kendisinden ve askerliğinden utandığını, üzüntüsünden yataklara düștüğünü yazar. ${ }^{54}$ Mehmet Narlı, Türk subayının aslı görevinin vatanı korumak ve milli bilinçle hareket etmek olması gerekirken, Bulgar kızı sayesinde buna ulaşmasını, "olması gerekenle, olanın karşıtlığına ve kişinin safderunluğuna" dayanan bir ironi olduğunu ifade eder. ${ }^{55}$

“Tuhaf Bir Zulüm” hikâyesinde de Rumeli'de/Balkanlarda Müslüman Türklere uygulanan bu kez işkencenin değişik bir boyutu hikâye edilir. Gospodin Kepazef, gençliğinde İstanbul'da okumuş, iyi Türkçe bilen, önceleri ihtilalci, sonra dahiliye memurluğu yapmış, birkaç ay da adliye nazırlığı yapmış bir diplomattır. Kepazef, Bulgaristan'dan Türkleri nasıl muhacerete zorladıklarını kendince bulduğu bir metot üzerinden anlatır. Deliorman'da kaymakamken tamamen Türklerin yaşadığı yerlere Makedonya'dan Bulgarları göç ettirir. Bu yeni gelen Bulgar göçmenlere de devlet desteği ile üçer dörder domuzlar dağıtıp, onları serbest bırakmasını söyler. Domuzlar etraftaki evlerin önünde, bahçelerde, çeşmelerde dolaşmaya başlamasıyla, yapılan şikâyetlerden de bir netice çıkmayınca, yavaş yavaş bütün Türkler İstanbul'a hicret eder. Böylece Deliorman hiç kurșun atılmadan Kepazef'in "domuz" fikriyle Bulgarlaştırılmıștır. ${ }^{56}$

Yazarın askerlik hatıraları arasında yazılan bir başka hikâye de "İrtica Haberi"dir. "Bir zabitin not defterinden" Köprülü notuyla verilen hikâyede, anlatıcı akşam taliminden sonra arkadaşlarından Selanikli Âkil'i bulduğundan bahseder. ${ }^{57}$ Vardar'ın ke-

51 Ömer Seyfettin, Bütün Hikâyeleri, s. 799.

52 Ömer Seyfettin, Bütün Hikâyeleri, s. 805.

53 Ömer Seyfettin, Bütün Hikâyeleri, s. 813.

54 "Nakarat" hikâyesinin gerçek hikâyesi için bkz. Önertoy,a.g.m.,s.76.

55 Mehmet Narl, “Ömer Seyfettin'den Cemal Şakar’a Öykü ve İroni”, İlmî Araştırmalar, 24, 2007, s. 107.

56 Ömer Seyfettin, Bütün Hikâyeleri, s. 820-821.

57 Polat, Selanikli Âkil'in yazarın yakın arkadaşlarından olan Âkil Koyuncu (1886-1977) olduğunu ve hikâyenin bir kurmaca metin olmasına rağmen yazarın hatıralarından hareket ettiğini belirtir. Bkz. Ömer Seyfettin, Bütün Hikâyeleri, s. 192. 
narında onunla geleceğe ait planlar ve İstanbul'daki gelişmeler hakkında konuşurlar. Bu hikâyede Ömer Seyfettin henüz savaştan bahsetmese de İstanbul'daki gelişmeleri dinledikten sonra gözünün önüne, “dumanlı bir Balkan haritası gelir.” Türkiye’nin parçalandığını, sınırların değiştirildiğini görür. Tıpkı daha önce benzer şeyleri anlatan Roland de Mares'in “Mal Ottoman” makalesini okuduğu gibi. Halk, Köprülü'de toplanıp istibdat aleyhine miting yapmaya başlamıştır. ${ }^{58}$ Yazarın 1 ve 2 Nisan 1909 tarihlerini taşıyan ve iki bölümden oluşan hikâyesinin yazıldığı dönemde henüz savaşın adı bile geçmemiştir. Ancak bir asker öngörüsüyle Ömer Seyfettin'in hikâyelerinde bu felaketleri rüya olarak da olsa dile getirmesi dikkat çekicidir.

\section{Birinci Dünya Savaşı Günlerinde Yazılan Hikâyeler}

Birinci Dünya Savaşı, tarih açısından harp edebiyatı ve propagandanın kullanıldığı ilk savaştır. ${ }^{59}$ Erkan-ı Harbiye Nezareti tarafından devrin önemli şair ve yazarları davet edilerek Çanakkale’ye götürülmüş, cepheler gezdirilmiş, bu vesileyle hem halkın bilgilendirilmesi, hem de harp edebiyatıyla ilgili şiir, makale, hikâye ve romanlar yazdırılarak savaşın, yaşanan kahramanlıkların ölümsüzleşmesi hedeflenmiştir. ${ }^{60}$ Çanakkale'ye davet edilen heyetin içinde yer alan isimlerden birisi de Ömer Seyfettin'dir. ${ }^{61}$ Yazarın "Kaç Yerinden” başlıklı hikâyesinde Birinci Dünya Savaşı'nda Çanakkale'de, Kafkas Cephesinde, Bağdat'ta Suriye'de, Makedonya'da hastanelerde kırk dokuz yerinden yaralanan bir kahramanın hikâyesi anlatılır. ${ }^{62}$ İstanbullu zengin bir ailenin oğlu olan bu kahraman, Almanya'da okumuş, olağanüstü sanatkâr kabiliyetine sahiptir. Harp ilan edilince "kemanın yayını bıraktığı eline silahı alarak talimgâha koşar." ${ }^{33}$ Sağ bacağını Galiçya'da kaybeden kahraman, askerlikten geri kalmamış, şimdi de hava kuvvetlerinde hizmete devam eder. ${ }^{64}$

Ömer Seyfettin'in bir asker olarak değil, yazar olarak takip ettiği Çanakkale Savaşını konu alan ilk hikâyelerinden birisi de "Bir Çocuk Aleko"dur. Gelibolu taraflarında bir fırıncının yanında çalışan Küçük Ali, “Muharebe olacak” gerekçesiyle hükümet tarafından ustası ve diğer Hristiyanlarla Anadolu`ya geçirilir. Gelibolu〉da akrabası ve

58 Ömer Seyfettin, Bütün Hikâyeleri, s. 194-199.

59 Bkz. Mustafa Selçuk, "Birinci Dünya Savaşı Sürecinde Harbiye Nezareti’nin Çanakkale Kahramanlığını Yaşatma Amaçlı Faaliyetleri, Avrasya İncelemeleri Dergisi (AVID), I/2, 2012, s. 195-242.

60 Köroğlu, Türk Edebiyatı ve Birinci Dünya Savaşı (1914-1918), s. 187-201.

61 İbrahim Alaettin Gövsa, Çanakkale İzleri: Anafartalar’ın Müebbet Kahramanına, Atatürk Kültür Dil ve Tarih Yüksek Kurumu Atatürk Kültür Merkezi Yayınları, Ankara 1989, s. 11.

62 Ömer Seyfettin'in başka hikâyelerinde de milli kahramanlıklarla ilgili pek çok tema işlenir. Kaplan, Ömer Seyfettin’in "Başını Vermeyen Şehit” gibi hikâyeleriyle “Birinci Dünya Savaşına katılan genç subaylara ve erlere tarihî kahramanlardan bir örnek vermek istediğini” söyler. Bkz. Mehmet Kaplan, Hikâye Tahlilleri, Dergah Yayınları, İstanbul 2005, s. 68.

63 Ömer Seyfettin, Bütün Hikâyeleri, s. 518.

64 Ömer Seyfettin, Bütün Hikâyeleri, s. 520. 
kalacak yeri olmayan Ali, köyündeki evleri kapanmış, ahırları boşalmış, küçük çarşı meydanı at, araba, asker, çadırlarla dolmuş bulur. "Buralarda muharebe olacak, devlet ahaliyi geri çekti” konuşmalarını duyar. O köyünün ahalisini, anasını, ihtiyar babasını arasa da bulamaz. Köye doğru gelenler ise, Rumlardır. Uzun süre Rumların arasında yaşadığından Rumca bilen Ali, köye doğru gelenlerin arasına karışır. Rumlar arasında adını Aleko olarak söyleyen Ali'yi, papaz kiliseye hizmetçi yapmak istese de, o bunu kabul etmez. ${ }^{65}$ Rumlar arasında muharebeye dair havadislerde, Türklerin kış geçmeden bozulacağı, İstanbul'un mutlaka alınacağı, Türklerin tamamen temizleneceği gibi şeyler vardır. Hâlbuki köyün altındaki şoseden durmadan Çanakkale'ye doğru, asker, araba, erzak, cephane gider. Ancak geçen zabitler Rum köylüler arasında neler konuşulduğunu, haklarında neler düşünüldüğü bilmezler. Papaz çok güvendiği Aleko'ya bir mektup vererek onu Çanakkale'de İngiliz komutana götürmesini söyler. Papazdan ve Rumlardan kahramanlık hikâyeleri dinleyen Aleko, milli bir bilinçle mektubu İngiliz komutan yerine, Türk subayına götürür. ${ }^{66}$ Rumlar arasındaki gelişmeleri aktararak, orduya yardımcı olmak istediğini söyler. Türk subayının emriyle İngilizler arasında bilgileri toplama görevini alınca da cepheye gider. İngilizler tarafından Türk askerleri arasında patlatması istenilen bombayı, orada patlatarak kendisi de şehit olur. ${ }^{67}$ Yazarın Birinci Dünya Savaşı konu alan diğer bir hikâyesi de “Çanakkale'den Sonra..." adını taşır. Yaşı kırk beşi geçmiş, hiç evlenmemiş anlatıcı, "Yarın Ruslar gelecek, İstanbul'u alacak. İngilizler ve Fransızlar Anadolu'yu yağma edecekler." diye düşünür. ${ }^{68}$ Umumi harp ilan olununca, İstanbul'da halk Anadolu'ya doğru hicret etmiştir. Ancak haftalar geçmesine rağmen, Ruslar İstanbul'a girememiş, İngiliz ve Fransızlar da Çanakkale'yi geçememiştir. Anadolu'ya hicret edenler de geri dönerler. Büyük yıkımlara sebep olan Çanakkale Savaş’ından sonra millet olma bilinci oluşmuştur. ${ }^{69}$

Yazar, I. Dünya Savaşı yıllarında asker olarak cephede değildir, ancak bir askeryazar olarak savaşın iç yüzünü en iyi bilenlerdendir. Bu dönemi anlatan hikâyelerinde askerlerin kahramanlıklarıyla beraber milli bilince vurgu yapan konuları işler.

\section{Harpten Sonra Yazılan Hikâyeler}

Ömer Seyfettin, hiçbir menfaat gözetmeden cephede savaşan, aç susuz kalan askerlerin kahramanlığını her zaman yüceltmiştir. Ancak vatan ve milli duygularını kaybederek zengin olma derdine düşen, bu sebeple topluma zulmeden savaş zen-

65 Ömer Seyfettin, Bütün Hikâyeleri, s. 1382.

66 Ömer Seyfettin, Bütün Hikâyeleri, s. 1388.

67 Ömer Seyfettin, Bütün Hikâyeleri, s. 1396.

68 Ömer Seyfettin, Bütün Hikâyeleri, s. 487.

69 Köroğlu, a.g.e., s. 369. 
ginleri onun hedefi haline gelir. Savaşın gölgesinde yazılan hikâyelerin önemli bir kısmında da bu konuları işler. Hikâyelerin ana teması, savaş ortamının getirdiği kıtlık ve yoksulluğu firsat bilip karaborsaya yönelen, haksız çıkar sağlayan, harp zengini "vurguncu" kișilerdir. ${ }^{70}$

Ömer Seyfettin "Bir Sultanî mualliminin hatırat defterinden üç dört sayfa" notunu düştüğü "Niçin Zengin Olamamış?” adlı hikâyesinde, savaş sonrası karaborsa (ihtikar) sayesinde büyük paralar kazanan ve zengin olan insanları eleştirir. Anlatıcl, muharebeden sonra açlık kasırgası içinde, karısının "annesinin evinden getirdiği çeyizler" de dahil, nesi var nesi yok satarak hayata tutunmaya çalıştıklarını, hatta "baba yâdigârı kütüphane"sini bile bit pazarında yok pahasına sattıklarını anlatır. Her geçen gün kendisini daha da hissettiren açlık ve kıtllk yüzünden satılacak elde bir şey de kalmamıştır. Anlatıcının meslek olarak yaptığı "Hocalık artık bir insanı değil, bir tavuğu bile besleyemez." durumdadir. ${ }^{71}$ Ancak memlekette halk ve vicdan sahibi okumuş, aydın kesimi bu şartlar altında yaşarken, kısa sürede zengin olan, semt değiştiren tipler de eksik değildir. Anlatıcının daha çok eğitimli kesimden ve yakın çevresinden çizdiği bu insanlar, kısa sürede para kazanmanın yolunu öğrenmiş ve zengin olmuşlardır. Zenginlik sevdasına düştükleri halde bunu başaramayanlar, yaptıklarından pişman olanlar da eksik değildir.

Hikâyede, yazarın mektepten arkadaşı olan kişi, okuyamadığı için okuldan kovulmuştur. Ancak savaş günlerinde tüccarlık işine girerek iki ay içinde çok büyük paralar kazanmıştır. Anlatıcının şaşırmasına da, "taraf-1 takribini bulursa çok kolay!" şeklinde izah getirir. Çünkü o da orduda iaşe nazırı olarak görev yapmıș birisi sayesinde zengin olmuştur. ${ }^{72}$

Zenginlik hayalinin "eter gibi birden tesir ettiği"ni gören anlatıcı, bu hayalini gerçekleştirmek üzere sermayesiz para kazanmanın yolunu öğretecek bu insanlarla tanışır. Arkadaşının tavsiyesiyle görüştüğü kişiden sonra, hayat standartları birden değişmeye başlar. Önce evini, sonra evin eşyalarını, sonra da okuldaki görevi için birini yerine kiralar. Askere alınma tehlikesinden dolayı da mektebi bırakmaz. Savaş döneminde halkın en çok ihtiyaç duyduğu şey, ekmektir. Dolayısıyla para kazanmak için seçilen yol zahire işidir. Piyasanın kurallarına uyanlar kısa sürede zengin olurlar:

"Herkesin emeli, felsefesi, arzusu bir: Para kazanmak! Mücerredat yok! Hayal yok! Oldukça karışık bir piyasa dalaveresi var. Açık gözlülük en büyük kuvvet..."tir. ${ }^{73}$

Muharebenin başında bu piyasaya girmiş olanlar şimdi çoktan köşeyi dönmüşlerdir. Bunların tam tersine, șehrin ortasında yoksulluğun, sefaletin kol gezdiği semt-

70 Köroğlu, a.g.e., s. 380-387.

71 Ömer Seyfettin, Bütün Hikâyeleri, s. 934-395.

72 Ömer Seyfettin, Bütün Hikâyeleri, s. 936.

73 Ömer Seyfettin, Bütün Hikâyeleri, s. 938. 
ler, açlıktan ölen insanlar da çoktur. Anlatıcı, hayatın bir başka cephesini yansıtan bu manzarayla Cerrahpaşa taraflarında yeni zenginlerden birisinin evine davetli olduğu bir gecenin sabahında karşılaşır. Sabahtan erkenden çıtığı için araba bulamaz ve Aksaray'a doğru iner. Valide Camii'nin yanından yukarı doğru yürür, Yirmi beş yirmi altı yıl önce Laleli'den Yeni Kapıya inen sokakların birinde oturdukları evi ve çevreyi hatırlar. Ancak etraf “Unutulmuş hatırat gibi... Bütün virane..."dir.

"Yarım kalmış bacalar, ocakların sahipsiz bir mezar sükutuyla uyu"duğu sokaklarda toplanan çocukların arasında görevliler açlıktan ölenleri toplarlar. Halkı bu hale getirenler, milletin yediği ekmekten çalan, ona hile karıştıran, fukarayı soyup zengin olan "hain"lerdir. Bunları görüp dinledikten sonra aklı başına gelen anlatıcı, milletten soyduğu bütün paraları "aşhanelere, fukaraperver cemiyetlerine" dağıtarak kiralık bir eve taşınır. Ancak vicdan azabını ölünceye kadar devam eder. ${ }^{74}$

Ömer Seyfettin'in mektup tekniğini kullanarak savaş zengini insanları anlattığ bir başka hikâyesi de "Memlekete Mektup"tur. İstanbul'da hukuk eğitimini tamamladıktan sonra Malatya'ya dönen anlatıcı, on beş yıl sonra bir vesile geldiği İstanbul'u çok değişmiş bulur. Cağaloğlu'nda kaldığı otel "kurûn-1 vustâ elemhanesine" benzer. Şehrin kalbi sayılan, matbuat dünyasının bulunduğu bu semtteki kitapçılar "Uzun günler, müşterisiz pinekleyen” bir pozisyondadırlar. Eski İstanbul'dan eser kalmamıştır. İmparatorluğun payitahtını bu duruma getiren etkenlerin başında şüphesiz, Balkan Savaşları ve devamında yaklaşık dört yıl süren Birinci Dünya savaşıdır. Bu iç karartıcı, yürek burkan manzaraları her tarafta görmek mümkündür:

"Sokaklar daralmış, insanlar küçülmüş, kadınlar sıskalaşmııs. Çehreler solgun. Herkeste üst baș perişan. İnanulmaz bir zaruret bu halkı eziyor. Mahallelerde birçok evler aç!"?’5

Hâlbuki aç, sefil halkın yanında hâlâ "kâş̧anelerde" yaşayan, otomobillerle gezenler de eksik değildir. İstanbul adeta ikiye bölünmüş gibidir. Savaşın getirdiği yoksulluğun, yıkımın izinin neredeyse hiç hissedilmediği Şişli, Nişantaşı, diğer tarafta ise açlık ve sefaletin kol gezdiği Aksaray ve Fatih. Savaş zamanında ortaya çıkan bu yeni zengin grup işi o kadar azıtmıştır ki, mallarını ve paralarını korumak için şehrin başka bir devlete verilmesini bile istemektedirler. Milli ticaret denilen ve savaş zamanında propagandası yapılan ticari hayat da Rumların ve Yahudilerin elindedir.

Bu iki farklı dünyayı, birbirine bağlayan "Köprü âdeta beynelmilel bir meşher"dir. İstanbul'un sokaklarına yansıyan bozulmuşluk, dağınıklık devlet dairelerinde de aynıdır. Matbuatta savaşa dair haberlere yer verilmezken, dedi koduyla doludur. İktidarda olanlar ve onun destekçileri de iki gruba ayrılmıştır. "Biri kuvvet ellerinde iken

74 Ömer Seyfettin, Bütün Hikâyeleri, s. 939-941.

75 Ömer Seyfettin, Bütün Hikâyeleri, s. 926. 
halkı soyup soğana çeviren yeni zengin sınıfı! Öteki firsatı kaçırıp umumî soyguna şahsî namus endişesiyle iştirak etmeyenler." ${ }^{76}$

Anlatıcının mektepte iken "Labori" adını taktıkları sınıf arkadaşlarından Mustafa Nazım, geçine bilmek için, "Harp esnasında yazıhanesini, evini, barkını, eşyasını, hâsılı nesi var, nesi yok, hepsini satmış, yemiş”tir. Adliyede bir odacı iken kısa sürede yeni zengin olan birsinin yanında katip olarak çalışmaktadır. Karşılaştığı diğer arkadaşı Ebulfuruva'nın ise, tam tersine kılık kıyafeti yerindedir. İlk başta anlatıcıyı "tanımamazlıktan gelse de, selamı almak durumunda kalır. Ebulfuruva hâlâ arkadaşının "milliyetperverlik" düşüncesine sahip olmasına şaşırır. Onun savunduğu, "yegâne selamet Türklüğü filan inkâr edip milliyetsiz dindar olmaktır." Onlar da İstanbul'un önde gelen isimlerin yer aldığ 1 "Tevhit ve Ahlak" adında bir cemiyet kurmuşlardır. ${ }^{77}$

Şehrin sosyal ve kültürel hayatında sanata ve edebiyata ilgi gösteren neredeyse yoktur. On beş yıl öncesinin edebiyat mahsulleri, Namık Kemal'in heyecanla şiirlerini okudukları, fikir teatileri yapılan sohbet ortamları ortadan kalkmıștır. "İstanbul meflûç bir gölge hâlinde uzanmış! Uyuyor. Fakat baygın. Bu cesedi kımıldatacak ruh ölü..... İstanbul savaşın ortaya çıkardığı yeni zenginler, menfaatçiler ve siyasî ortam yüzünden "ruhu ölü" bir şehir haline gelmiştir. Ancak yine de ümit tamamen kaybolmamıştır. Hikâyede İstanbul'un manevî değerler açısından ne kadar çöküntüye uğradığı kişiler üzerinden anlatılır. ${ }^{78}$

Ömer Seyfettin'in savaş sonrasında kaleme aldığı hikâyelerden birisi de "Yusuf Borusu Seni Bekliyor"dur. Bu kez hikâyenin merkezinde askeriyeden birisidir. Aksaraylı Cabir Paşa, saraya mensup bir eş sayesinde kısa sürede terfi ederek "ferikliği yakalamış"tır. Ancak şartlar değişip, orduyu gençleştirme sevdasına düşenler başa gelince, Cabir Paşa da emekliye sevk edilenlerdendir. Eşi vefat ettiği için tek başına yaşayan paşa, tekaüt maaşıyla bir süre idare etse de, bakkal açarak ticarete atılır. Ancak o, "vesika şekerini" dağıtırken ufaktan halkın hakkından kesintiler yapmaya başlar. Mahalleli kadınların, "Sen hükümet kapısında yetim hakkı yemeye alışmışsın... Galiba şimdi de mahalle bakkallığını mı yiyim yeri yaptın?” çıkışlarıyla burayı başkasına devrederek kaçar. Ancak paşa, para kazanmanın yolunu ve tadını almıştır. Kısa yoldan para kazanmak için belli isimlerin peşine takılmak, metodunu bilmek yeterlidir. O da kısa sürede tavsiyeler, himmetler ve biraz da etek öpmelerle muradına nail olur. Daha sonra girdiği ihracat vesikası işinin de modası geçtiği için fazla para kazanamadan onu da kapatmak zorunda kalır. Bu işten mahrum kalan açıkgözler "iaşe" işinde işlerini yürütmeye devam etseler de, o bu işin yolunu ve yöntemini bulamaz ve itibarını kaybetmiş bir emekli asker olarak yeniden askerlik mesleğine döner. ${ }^{79}$

76 Ömer Seyfettin, Bütün Hikâyeleri, s. 927.

77 Çağın, a.g.m., s. 227-228.

78 Hüseyin Gürbüz, “Sosyal Meseleler Açısından Ömer Seyfettin’in Hikâyeleri”, Hece, 46/47, Ankara Ekim-Kasım 2000, Türk Hikâyeciliği Özel Sayısı, s. 201.

Ömer Seyfettin, Bütün Hikâyeleri, s. 1090-1093. 
"Zeytin Ekmek" hikâyesi yazarın Birinci Dünya Savaşı'nın sonunda, aç ve sefil kalan kadınların nasıl istismar edildiğini anlatır. Rumeli'de aynı kazada Naciye ve Sabire çocukluk arkadaşıdırlar. Ancak Balkan bozgunu sırasında kaçarken birbirini kaybederler. Birinci Dünya Savaşından sonra tekrar karşılaştıkları zaman, Naciye fakir bir hayatın içinde "Gece gündüz vesika ekmeği.. katık zeytin.." yaşar durumdayken, arkadaşı zengin çevrelerde, lüks bir hayatın içindedir. ${ }^{80}$ Arkadaşı tarafından zengin bir erkekle tanıştırılan Naciye, "Bir gecelik misafirlik! Ne olur? Bari doya doya bir yemek yerim!" ${ }^{81}$ düşüncesiyle gittiği köşkte de, zeytin ve vesika ekmeğiyle karşılaşınca, açlık için namusunu feda etmeden oradan ayrılarak uzaklaşır. ${ }^{82}$

Savaş sonrasının sosyal hayattaki yansımalarına yer verilen hikâyelerin sonuncusu yazarın vefatından sonra yayımlanan "Foya"dır. Yazarın yakın arkadaşı Ali Canip, "Foya" için, "Birinci Dünya Harbi içinde peyda oluveren zenginlerin hayatını tasvir edecekti." açıklamasını yapar. ${ }^{83}$ Hikâyenin anlatıcısı gazeteci, eski bir mebusun küçük bir sarayı andıran konağına gider. Konağın içerisi de dışarısı kadar gösterişli ve pahalı malzemelerle kaplıdır. "Şişman ve kaba" bir adam olan konağın sahibi mebusun parmakları da tıpkı konak gibi "çakıl çukul yüzük içinde"dir. ${ }^{84}$ Muharebe içinde hayatının bir kısmını yurt dışında Bükreș’te, Viyana'da, Berlin'de hatta İsviçre'de geçirmiş eski mebusun dünyasında para kazanmanın dışında bir şey yoktur. Tevfik Fikret'in Rübâb-ı Şikeste şiir kitabının adını bile bilemeyen mebus, şairin, o mebusken maarif nazırı tarafından Galatasaray'ın müdürlüğünden alınmasını da gazetecinin hatırlatmasıyla hatırlayabilir. İttihatçılar sayesinde zengin olan mebus, gelişen siyasi pozisyona göre bir cepheden öbürüne geçmesi an meselesidir. Kendi ifadesiyle "Benim sırtımda yumurta küfesi yok. Biz zamaneye uyarız." 85

Bir fikre sahip olmayan, sürekli "pohpohlanmaya" alışmış mebus, savaş ortamında çok para kazandığı için kendisini akıllı zanneder. Bu özelliğini bildiği için gazeteci ona, "dâhi" olabileceğini söyler. Çünkü "Amerika'da, Avrupa'da, hatta Afrika'da para kazanmak o kadar güç bir şey değildi. Çünkü birtakım iktisat müesseseleri, sermaye, sanayi, banka, tröst filan vardı. Fakat Türkiye'de... Bu aç, bu çılak yerde öyle Avrupa'da, Amerika'da olduğu gibi otuz kırk sene içinde değil, otuz kırk ay, hatta birkaç gün içinde milyoner oluvermek..." ${ }^{86}$

Ömer Seyfettin'in ironik bir üslupla anlattığı eski mebusa gazeteci, hatıralarını başkasının hayatını yazıyormuş gibi yazmasını, iyilikleri kendisine, her fenalığı da in-

80 Ömer Seyfettin, Bütün Hikâyeleri, s. 1027.

81 Ömer Seyfettin, Bütün Hikâyeleri, s. 1029.

82 Uğurcan, a.g.m., s. 275.

83 Ali Canip Yöntem, Ömer Seyfettin (1884-1920): Hayatı, Karakteri, Edebiyat, İdeali ve Eserlerinden Numuneler, Remzi Kitabevi, İstanbul 1947, s. 32.

84 Ömer Seyfettin, Bütün Hikâyeleri, s. 1048.

85 Ömer Seyfettin, Bütün Hikâyeleri, s. 1411.

86 Ömer Seyfettin, Bütün Hikâyeleri, s. 1413. 
tikam alamayacak olan "ölenlere” yüklemesini salık verir. Bu fikri pek beğenen mebus buradan bir "roman" çıkabileceğiyle işe koyulur.

Savaş dönemlerinde en önemli şey milli birlik ve bütünlüktür. Ortak üzüntü ve sevinci paylaşmak esastır. Bununla beraber -sayıları fazla olmasa da- fırsat düşkünü, milli bilinci teşekkül etmemiş insanlar da eksik olmamıştır. Bunlar arasında avamdan insanlar olabildiği gibi, makam mevki sahibi olmuş, eğitimli kişiler de çıabilir. Yazar bu bölümde fırsat düşkünü, savaş ortamını kazanca (!) dönüştürme peşinde olanları canlı bir şekilde anlatır. Toplumun önüne onları en kötü örnekler olarak çıkartır.

\section{Sonuç}

Türk hikâyesinin öncü isimlerinden Ömer Seyfettin, asker olarak Rumeli/ Balkanlar'da görev yaparken yakın tanığı olduğu baskı ve zulümleri, savaş günlerinde çekilen acıları ve bu dönemde sosyal hayatın olumsuz bir yönünü oluşturan fırsat düşkünü yeni zenginleri hikâyelerinde geniş olarak işler. Yazar hikâyelerinde kendi askerlik hatıralarından ve günlüklerinden faydalanır, ayrıca günlük ve mektup gibi edebî türleri de hikâyelerinde kullanır. Savaşın gölgesinde yazılan "Beyaz Lale" ve “Tuhaf Bir Zulüm” adlı hikâyelerinde Rumeli/Balkanlar'da yaşayan Müslüman Türk halkının komitacılar tarafında nasıl zulüm ve tecavüze uğradıkları anlatılır. "Bomba" ise, devlet otoritesinin zayıflamasıyla ortaya çıkan komitacıların, sadece Türklere değil, kendi soydaş/dindaşlarına bile zulmetmekten çekinmediklerini anlatan bir hikâyedir. "Nakarat” da Balkan Savaşları öncesinde bölge insanının Müslüman Türklere bakışını göstermesi açısından önemlidir. Savaş milletleri yerinden yurdundan etmekle kalmaz, farklı milliyetlere mensup kişilerin kurduğu aileleri de parçalar. Ama aynı zamanda milli bilinçten mahrum şekilde yaşayan insanların bilinçlenmesine de vesile olur. Buna benzer düşünceler "Primo Türk Çocuğu” hikâyesinde dile getirilir.

Savaş öncesinde başlayan ve savaş günlerinde de devam eden "Ashab-1 Kehfimiz" hikâyesinde, belli bir milli bilince sahip olmayan ve düşünce akımlarından da etkilenen insanların kurdukları hayallerin nasıl boşa çıktığı anlatılır. Esas muharebeyi konu alan "Kaç Yerinden”, "Bir Çocuk Aleko” gibi hikâyeler ise, vatan için her şeyini feda eden kahramanların öykülerine yer verir.

Savaş demek, açlık, yoksulluk ve ölüm demektir. Dolayısıyla vatanı için varını yoğunu, canını feda edenlerin yanında halkı istismar eden, fırsat düşkünü karaborsacı tipler de eksik değildir. Ömer Seyfettin'in halkın her kesiminden farklı tiplerin anlatıldığı hikâyeleri arasında, bu tür olumsuz örneklere de yer verilir."Harpten Sonra”, "Niçin Zengin Olmamış", "Memlekete Mektup", "Yuf Borusu Seni Bekliyor", "Foya'dan" gibi hikâyeleri böyledir.

Sonuç olarak, onun hikâyelerinde Balkan Savaşı öncesinden başlayıp Birinci Dünya Savaşı sonrasına kadar devam eden süreçte, cephede ve cephe gerisinde yaşananların olumlu ve olumsuz bütün yönleri canlı bir şekilde okunabilir. 


\section{KAYNAKÇA}

Alangu, Tahir, Ömer Seyfettin: Ülkücü Bir Yazarın Romanı, Yapı Kredi Yayınları, İstanbul 2010.

Cunbur, Müjgan, “Ömer Seyfettin'in Hayatı ve Eserleri”, Doğumunun 100. Yllında Ömer Seyfettin, Türk Tarih Kurumu Basımevi, Ankara 1992, s. 1-18.

Çağın, Sabahattin, “Fikir Akımları Karşısında Ömer Seyfettin”, Ömer Faruk Huyugüzel’e Armağan(ed. Halef Has), Ege Üniversitesi Basımevi, İzmir 2010, s. 223-234.

Demir, Yavuz, “Ömer Seyfettin'in Hikâyelerinde Bulgar Zulmü”, Türk Edebiyatı, 170, Aralık 1987, s. 59-60.

Duman, Halûk Harun, Balkanlara Veda, Duyap Yayınları, İstanbul 2005.

Enginün, İnci, “Ömer Seyfettin'in Hikâyelerinde Yabancllar”, Doğumunun Yüzüncü Yılında Ömer Seyfettin, Marmara Üniversitesi Yayınları, İstanbul 1984, s. 51-78.

Enginün, İnci, “Ömer Seyfettin'in Hikâyeciliği”, Doğumunun 100. Yllında Ömer Seyfettin, Atatürk Kültür, Dil ve Tarih Yüksek Kurumu Atatürk Kültür Merkezi Yayınları, Ankara1992, s. 37-49.

Enginün, İnci, “Ömer Seyfettin’in Hikâyeleri”, Yeni Türk Edebiyatı Araştırmaları-1, Dergâh Yayınları, İstanbul 2012, s.167-176.

Gövsa, İbrahim Alaettin, Çanakkale İzleri: Anafartalar'ın Müebbet Kahramanına, Atatürk Kültür Dil ve Tarih Yüksek Kurumu Atatürk Kültür Merkezi Yayınları, Ankara 1989.

Güneş, Mehmet, "XX. Yüzyılın Başlarında Balkanlardaki Siyasî ve Etnik Çatışmaların Ömer Seyfettin'in Hikâyelerine Yansıması",TÜBAR, XXIX, Bahar 2011, s. 163-187.

Gürbüz, Hüseyin, “Sosyal Meseleler Açısından Ömer Seyfettin'in Hikâyeleri”, Hece, 46-47, Ekim-Kasım 2000, Türk Hikâyeciliği Özel Sayısı, s.199-211.

Huyugüzel, Ö. Faruk, “Ömer Seyfettin'in İzmir Yılları ve Bu Devrede Yazdığı Hikâyeler”, İzmir'de Edebiyat ve Fikir Hareketleri Üzerine Araştırmalar, İzmir Büyükşehir Belediyesi Kültür Yayını, İzmir 2004, s. 208-223.

Kaplan, Mehmet, Hikâye Tahlilleri, Dergâh Yayınları, İstanbul 2005.

Karaca, Alaattin, “Ömer Seyfettin'in Hikâyelerinde Balkanlar”, Bir Dünya Yazarı Ömer Seyfettin Sempozyumu Bildirileri, İstanbul Büyükșehir Belediyesi Yayınları, İstanbul 2011, s. 76-91.

Koç, Murat, “Ömer Seyfettin'in Eserlerinde II. Meşrutiyet ve İttihat ve Terakki”, Bilig, 47, Güz 2008, s. 121-146.

Köroğlu, Erol, Türk Edebiyatı ve Birinci Dünya Savaşı (1914- 1918): Propagandadan Milli Kimlik İnşasına, İletişim Yayınları, İstanbul 2004.

Narl, Mehmet, “Ömer Seyfettin'den Cemal Şakar’a Öykü ve İroni”, İlmî Araştırmalar, 24, 2007, s. 103-115.

Ömer Seyfettin, Makaleler-1 (hzl. Hülya Argunşah), Dergâh Yayınları, İstanbul 2001, s. 5-16.

Ömer Seyfettin, Bütün Hikâyeleri (hzl. Nâzım Hikmet Polat), Yapı Kredi Yayınları, İstanbul 2011. 
Önertoy,Olcay,“ÖmerSeyfettin'inMilliyetçilikDüşüncesi”,Doğumun100.YllındaÖmerSeyfettin, TürkTarihKurumuBasımevi,Ankara 1992, s.73-85.

Polat, Nâzım Hikmet, “Ömer Seyfettin Hakkında”, Ömer Seyfettin, Bütün Hikâyeleri (hzl. N. Hikmet Polat), Yapı Kredi Yayınları, İstanbul 2011, s. 1-34.

Polat, Nâzım Hikmet, “Ömer Seyfettin,” TDV İslam Ansiklopedisi (DİA), İstanbul 2007, c. 34, s. $80-82$

Polat, Nâzım Hikmet, Şair Ömer Seyfettin Bütün Şiirleriyle, Türk Dil Kurumu Yayınları, Ankara 2014.

Selçuk, Mustafa, "Birinci Dünya Savaşı Sürecinde Harbiye Nezareti’nin Çanakkale Kahramanlığını Yaşatma Amaçlı Faaliyetleri”, Avrasya İncelemeleri Dergisi(AVID), I/2, 2012, s. 195 242.

Torun, İbrahim, “Ömer Seyfettin’in Askerlik ile İlgili Görüşleri ve Öykülerindeki Asker Tipleri”, Türk Dili, 634, Ekim 2004, s. 477-488.

Tural, Sadık, “Ömer Seyfettin’in Hayatı ve Eserleri”, Doğumunun 100.Yılında Ömer Seyfettin, Marmara Üniversitesi Yayınları, İstanbul 1984, s. 9-39

Uğurcan, Sema, “Ömer Seyfettin’in Hikâyelerinde Kadın Tipleri”, Edebiyatımız-II: Yazarlar, Meseleler, Dergâh Yayınları, İstanbul 2012, s. 268-283.

Yöntem, Ali Canip, Ömer Seyfeddin (1884-1920) :Hayatı, Karakteri, Edebiyatı, İdeali ve Eserlerinden Numuneler, Remzi Kitabevi, İstanbul 1947. 